\title{
Comparison of Nutritional Composition of Bird Egg Varieties Found in Southern Nigeria: A Preliminary Study
}

\author{
Eridiong 0. Onyenweaku1, Henrietta N. Ene-Obong1, Ima 0. Williams ${ }^{1}$, \\ Chinaka 0. Nwaehujor ${ }^{2 *}$ \\ ${ }^{1}$ Human Nutrition and Dietetics Unit, Department of Biochemistry, University of Calabar, Calabar, Nigeria \\ ${ }^{2}$ Department of Biochemistry, Faculty of Basic Medical Sciences, University of Calabar, Calabar, Nigeria \\ Email: *chinaka_n@yahoo.com
}

How to cite this paper: Onyenweaku, E.O., Ene-Obong, H.N., Williams, I.O. and Nwaehujor, C.O. (2018) Comparison of Nutritional Composition of Bird Egg Varieties Found in Southern Nigeria: A Preliminary Study. Food and Nutrition Sciences, 9, 868-879.

https://doi.org/10.4236/fns.2018.97065

Received: October 18, 2017

Accepted: July 23, 2018

Published: July 26, 2018

Copyright (c) 2018 by authors and Scientific Research Publishing Inc. This work is licensed under the Creative Commons Attribution International License (CC BY 4.0).

http://creativecommons.org/licenses/by/4.0/

\begin{abstract}
This study was aimed at comparing nutrient composition of some bird eggs in their raw and boiled forms. The different varieties were exotic chicken, local chicken, turkey, quail and guinea fowl eggs. The eggs were shelled and their contents (boiled and raw) lyophilized. Standard AOAC methods were used for determination of proximate, mineral and vitamin compositions. Results showed the boiled eggs having higher nutrient concentrations than the raw eggs across all species. Guinea fowl egg had significantly higher $(\mathrm{p}<0.05)$ content of protein, fat and most micronutrients. The eggs were rich in microelements, with guinea fowl egg having the best sodium-potassium ratio $(0.66)$. Turkey eggs had significantly $(\mathrm{p}<0.05)$ higher iron content in the raw and boiled samples $(7.2 \pm 0.09 \mathrm{mg} / 100 \mathrm{~g}$ and $9.6 \mathrm{mg} / 100 \mathrm{~g}$, respectively). This study showed some "less-popular"/underutilized eggs having certain nutrients in significantly greater quantities; hence exploiting these may greatly improve diet quality and nutritional status of consumers.
\end{abstract}

\section{Keywords}

Egg, Chicken, Turkey, Quail, Guinea Fowl, Nutrient, Mineral, Vitamin

\section{Introduction}

Malnutrition (undernutrition and over-nutrition) has continued to be a public health challenge all over the world, but particularly in low and middle-income countries including Nigeria [1]. According to the 2015 global nutrition situation, malnutrition affects one in three people on the planet [2]. Two billion people 
experience micronutrient deficiencies [1]; 1.9 billion adults are overweight or obese [1] and 161 million children under age 5 are stunted [3]. Among the many causes of malnutrition is the drastic change in food consumption pattern of populations around the world, especially those in rapid nutrition transition with the result that locally available nutrient-dense foods have been replaced by a few foods that are energy-dense [4]. Coupled with this, it has been estimated that in the ecosystem, crops alone supply $95 \%$ of dietary energy and protein supplies, while in the animal kingdom only five animal source foods provide micro and macro nutrient [5]. There are however many more animal source foods which should be explored in order to improve food security and narrow the protein gap still persisting in many low and middle-income countries. Among these animal food sources are eggs, fish, snails and insects. The nutrient composition of various foods depends on several factors which include species, breeds, cultivars, ecological factors, post-harvest handling, preservation and storage techniques [4]. Some foods are considered healthy depending on their nutrient content, while others are considered to be unhealthy [5].

Eggs are a relatively cheap and accessible source of essential nutrients and have been consumed by humans for many centuries. According to Pamplona-Roger, egg protein has a biological value (BV) of 1 , and is usually used as a reference standard to compare proteins from other sources (whose BV are usually less than 1); eggs provide the most complete protein of any food, together with fats, vitamins and minerals [6]. This means that eggs can be used to solve the problems of protein and micronutrient deficiencies.

Unfortunately, egg consumption is affected by several factors. In some cultures, egg consumption is restricted for women and children [7]. Furthermore, with the increasing prevalence of non-communicable diseases (NCDs) egg consumption is also reduced because of their high cholesterol content. It must however be noted that the exotic hen eggs is the most commonly consumed. There are other egg species which are underutilized that may be beneficial if exploited. It has been noted that modern agricultural systems have played a key role in reducing diversity in the food system by promoting the use of a particular specie in preference to genetically diverse traditional or farmers' varieties [5] [8]. Consumption of different varieties/breeds/cultivar of food can make significant impact on nutrition and health outcomes [4]. Unfortunately, this has not been the case because of lack of information on the nutritional value of these varieties/breeds/cultivars.

In Nigeria and other parts of the world, eggs are consumed mainly as protein foods but are also widely used in the baking industry. Although chicken eggs are currently most commonly eaten by humans, the eggs from other birds are also used for daily consumption. For example, Japanese quail eggs are gaining popularity in Europe and America, ostrich eggs in South Africa and duck eggs in Asian countries [9]. Some eggs are consumed raw for certain perceived health reasons and this has become quite popular in the recent past. 
This study is aimed at determining the nutrient composition of exotic chicken, local chicken, turkey, quail and guinea fowl eggs, in order that their potentials can be exploited for nutrition-sensitive agricultural practice, enhance food security and improve nutritional status. Data generated from this study will also contribute to the nutrient composition database useful in the assessment of dietary intake of individuals/population groups, a major prerequisite for solving the problem of malnutrition in developing countries.

\section{Materials and Methods}

\subsection{Sample Collection and Identification}

Fresh eggs were purchased from poultries in Calabar, Cross River State and Nsukka, Enugu State, Nigeria and the species were identified Dr. Glory Enyenihi of the Animal Science Department, Faculty of Agriculture, University of Calabar, Nigeria before being transported to the laboratory to be prepared for analyses. The five egg species in this study are exotic chicken (Gallus domesticus), local chicken (Gallus gallus), turkey (Meleagris gallopavo), quail (Cortunix japonica) and guinea fowl (Numida melleagris).

\subsection{Raw Egg Preparation}

Shells of the fresh eggs were cleaned, broken and the contents emptied into clean, labelled glass beakers. The raw egg content was then homogenized and frozen at $-40^{\circ} \mathrm{C}$. The homogenized raw egg samples were lyophilized with using a freeze-drier (VirTis, Gardener, New York).

\subsection{Boiled Egg Preparation}

The fresh eggs were cleaned, labelled and boiled by putting them in tap water already boiling at $100^{\circ} \mathrm{C}$. The tap water was enough to cover the eggs in the pot. The eggs were left to boil for 10 mins, immediately after which they were removed and allowed to cool in tap water at room temperature. The different eggs were boiled separately and then shelled after they had cooled. The boiled eggs were placed in clean, labelled beakers and sealed with parafilm prior to undergoing freeze-drying. The boiled, whole (shelled) eggs were mashed and then freeze-dried with a freeze-drier.

All freeze-dried samples were milled to give fine powder, using a laboratory miller (Breville kitchen Wizz BFP650). Milling was done under very low temperature. After milling, $50 \mathrm{~g}$ of each of sample (raw and boiled freeze-dried samples) were refrigerated in labelled, air-tight sample glass bottles until ready for analyses.

\subsection{Chemical Analyses}

\subsubsection{Proximate Analysis}

The moisture, protein, fat, carbohydrate and ash contents of the samples were determined by the methods of the Association of Official Analytical Chemists 
[10]. In brief, moisture content was determined by drying a portion ( $5 \mathrm{~g})$ of the freeze-dried egg samples (both raw and boiled) to a constant weight, using a vacuum oven (Astell-Hearson) at $100^{\circ} \mathrm{C}$ for about $6 \mathrm{~h}$. The moisture content (MC) was taken as the difference in weight between the initial and the constantly dried samples. This procedure was also repeated directly on the fresh (non-lyophilized) egg samples and MC values were recorded. A water conversion factor (WCF) for the different species of eggs was calculated. The WCF was used to convert the dry sample values to values as consumed.

$$
\mathrm{WCF}=\frac{100-\% \mathrm{MC} \text { of fresh sample }}{100-\% \mathrm{MC} \text { of freeze }- \text { dried sample }}
$$

Fat content was determined by exhaustive extraction of $5 \mathrm{~g}$ of the freeze-dried samples with analytical grade petroleum ether using a Soxhlet apparatus (Corning, England). The protein content was determined by the micro-Kjeldahl digestion apparatus. The method estimated the amount of nitrogen in the sample which was subsequently used to calculate the protein content by multiplying with the factor of 6.25. Total ash was determined from the residue left after incinerating a $5 \mathrm{~g}$ portion of the freeze-dried samples in a muffle furnace at $550^{\circ} \mathrm{C}$. Carbohydrate (sugars) were extracted from the egg samples with water, clarified and chromatographically separated on an amine column with an acetonitrile/water mobile phase. Total carbohydrate was calculated by difference; that is, by subtracting the sum of moisture, protein, fat and ash from 100 (expressed in percentage). The sugars were detected using an evaporative light scattering detector and quantified with reference to calibration standards [10] [11]. The caloric (energy) value of the samples was obtained by complete combustion of the samples using a bomb calorimeter. Also, calculated energy values were obtained by multiplying the values of the crude protein, crude fat and digestible carbohydrate by the Atwater factors of 4,9 , and 4 respectively and taking a sum of the products. This was expressed as $\mathrm{KCal} / 100 \mathrm{~g}$ of the sample [12]. That is, Energy = [protein $(\times 4)+$ fat $(\times 9)+$ carbohydrate $(\times 4)] \mathrm{KCal} / 100 \mathrm{~g}$.

\subsubsection{Estimation of Mineral Elements}

The mineral elements were determined using sample digests prepared by digesting completely $5 \mathrm{~g}$ of the samples in perchloric and concentrated nitric acid, diluted with deionized water in a $50 \mathrm{ml}$ volumetric flask. Phosphorus (P), Sodium $(\mathrm{Na})$, calcium $(\mathrm{Ca})$, iron $(\mathrm{Fe})$, zinc $(\mathrm{Zn})$ and potassium $(\mathrm{K})$ in the digest were estimated using the Perkin Elmer Atomic absorption spectrophotometer (Model 306, UK) [13].

\subsubsection{Estimation of Vitamins}

Vitamins $\mathrm{A}, \mathrm{D}$, and $\mathrm{E}$ were determined using a procedure involving saponification of the samples, solvent extraction and spectrometric determination at specific wavelengths [14]. Riboflavin (vitamin B2) and pyridoxine (vitamin B6) were determined by HPLC after appropriate and controlled acid and enzymatic hydrolysis. Cyanocobalamin (vitamin B12) was extracted by autoclaving in ace- 
tate buffer in the presence of cyanide and determined by microbiological assay using L. Delbrueckii lactis. All analyses were done in triplicates.

\subsection{Statistical Analysis}

Mean and standard error of mean were calculated and analysed using the oneway Analysis of Variance (ANOVA) in the Statistical Package for Social Sciences (SPSS), version 20 at 5\% significance level; LSD was used for multiple comparisons. Results were expressed as mean \pm Standard Error of Mean (SEM).

\section{Results}

\subsection{Proximate Composition and Energy Value of Eggs}

The results of the proximate composition and energy value of the five raw and boiled eggs presented in Table 1 indicate that, protein content varied significantly ( $\mathrm{p}<0.05)$ among all the raw samples with guinea fowl egg having the highest protein content $(20.3 \% \pm 0.15 \%)$ and turkey egg having the lowest $(11.5 \% \pm 0.44 \%)$. Raw guinea fowl egg also had the highest fat content $(13.8 \% \pm$ $0.17 \%)$ and this was significantly $(\mathrm{p}<0.05)$ higher than the others. Total carbohydrate and sugar content were low in all the raw eggs and some of the values were statistically different $(p<0.05)$. Calculated energy values were much lower than those gotten by bomb calorimetry; in the raw eggs, calculated values ranged from $628 \mathrm{KJ}$ to $871 \mathrm{KJ}$ and varied greatly among the egg species with guinea fowl egg recording the highest value. Among the boiled eggs, a similar trend was observed with guinea fowl egg having the highest protein and fat contents $(26.6 \% \pm$ $0.06 \%$ and $18.0 \% \pm 0.15 \%$, respectively) and this was significantly $(\mathrm{p}<0.05)$ higher than the others. Boiled turkey egg had the highest ash content $(5.4 \% \pm$ $0.03 \%)$ and this was significantly greater than the others which ranged between $1.7 \%$ to $4.0 \%$. Comparing both raw and boiled samples, it was generally observed that the raw eggs had higher moisture content and the boiled eggs had higher dry matter composition.

\subsection{Mineral Composition}

Figure 1 shows the mineral composition in $100 \mathrm{~g}$ of the raw and boiled egg samples. Of all the elements analyzed, phosphorus had the highest concentrations with guinea fowl egg recording significantly $(\mathrm{p}<0.05)$ greater values among both raw and boiled samples $(386.4 \pm 0.23 \mathrm{mg} / 100 \mathrm{~g}$ and $516.2 \pm 0.34 \mathrm{mg} / 100 \mathrm{~g}$, respectively). Phosphorus concentrations was closely followed by sodium and potassium. Calcium was also found in appreciable quantities in all the raw and boiled samples with turkey eggs having the highest values of $113.1 \pm 0.15$ $\mathrm{mg} / 100 \mathrm{~g}$ and $156.9 \pm 0.06 \mathrm{mg} / 100 \mathrm{~g}$ (in the raw and boiled samples respectively). Between the two microelements, iron was more abundant, with turkey eggs having significantly $(\mathrm{p}<0.05)$ greater values both in the raw and boiled samples $(7.2 \pm$ $0.09 \mathrm{mg} / 100 \mathrm{~g}$ and $9.6 \mathrm{mg} / 100 \mathrm{~g}$, respectively). Local chicken egg and exotic chicken egg had the lowest iron content of $2.1 \mathrm{mg} / 100 \mathrm{~g}$ and $2.4 \mathrm{mg} / 100 \mathrm{~g}$, respectively. 

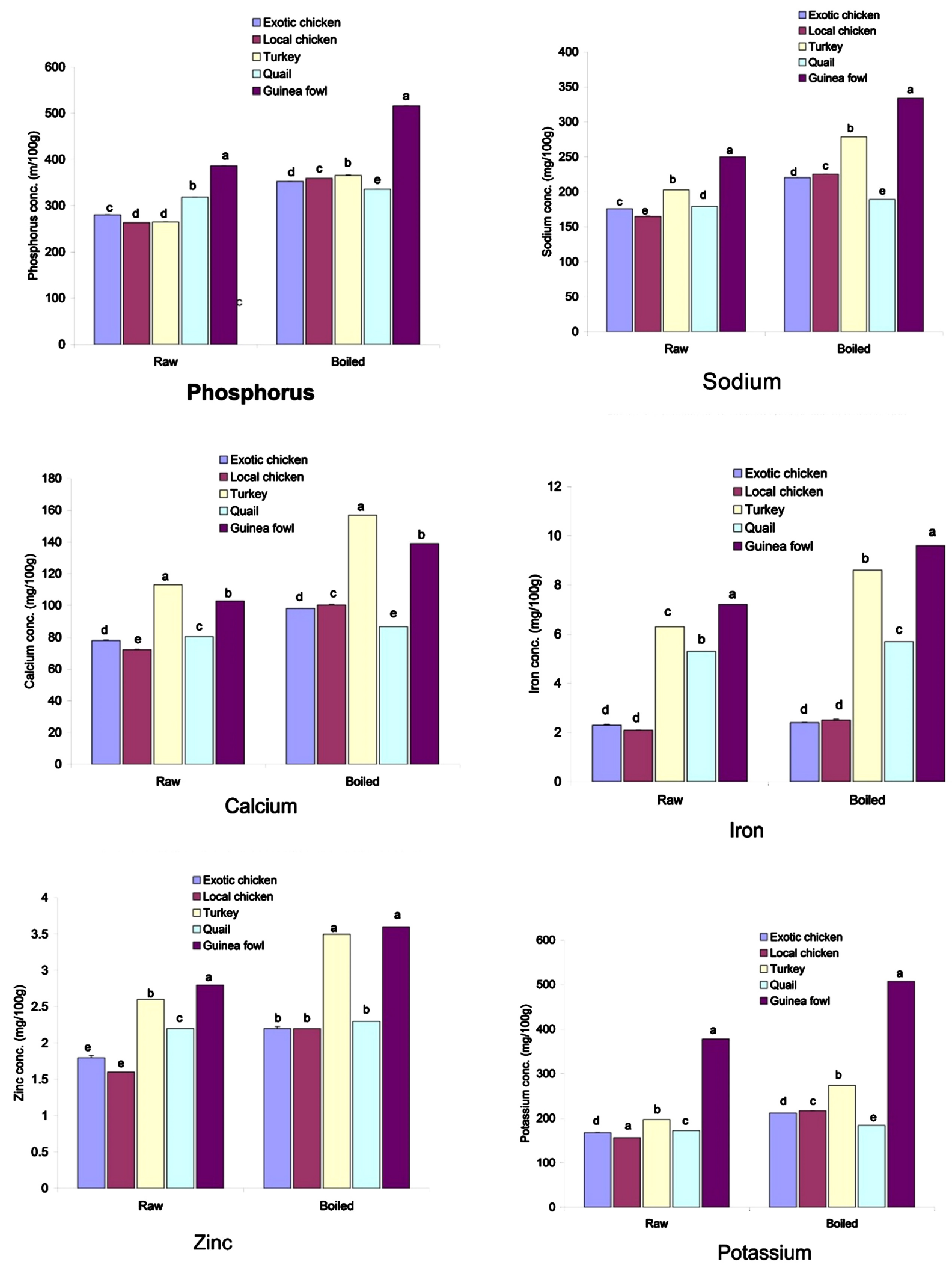

Values are presented as mean \pm SEM of 3 determinants Samples with similar symbols are homogenous

Figure 1. Comparison of mineral composition of raw and boiled eggs per $100 \mathrm{~g}$ of edible portion. 
Generally, the boiled eggs had higher elemental compositions than the raw egg samples.

\subsection{Vitamin Content}

In Figure 2, the vitamin composition in $100 \mathrm{~g}$ of the raw and boiled egg samples is recorded. Guinea fowl egg contained significantly $(\mathrm{p}<0.05)$ higher amounts of vitamin $\mathrm{A}$ in both the raw $(234.9 \pm 0.44 \mathrm{mcg} / 100 \mathrm{~g})$ and boiled $(312.1 \pm 0.52$ $\mathrm{mcg} / 100 \mathrm{~g}$ ) samples. Vitamin D was found in trace amounts in all the raw and boiled eggs except in raw exotic chicken egg $(60.6 \pm 0.25 \mathrm{mg} / 100 \mathrm{~g})$ and local chicken egg $(54.4 \pm 0.37 \mathrm{mg} / 100 \mathrm{~g})$. Vitamin $\mathrm{E}$ was also found in trace amounts in raw and boiled turkey eggs but the other species contained significant amounts ranging between 1.0 to $1.9 \mathrm{mg} / 100 \mathrm{~g}$ ). Vitamin $\mathrm{B}_{2}$ mean values were homogenous for all the raw and boiled egg samples except for raw exotic chicken egg $(0.5 \mathrm{mg} / 100 \mathrm{~g})$ which was significantly $(\mathrm{p}<0.05)$ higher than the other raw samples.

\section{Discussion}

Protein was the highest nutrient in the eggs except in raw and boiled turkey eggs where the lipid content was slightly higher than protein. This is in accordance with most of the researches carried out on different eggs where the protein content is greater than the fat content [15] [16]. However, this partly contrasts with the report of Fakai et al. [17] which reported that all the six raw egg species studied had a higher lipid content than protein (Table 1). The observed variation may be attributed to differences in study design, analytical methods used, species of bird eggs analysed, and feed composition of the birds.

These results show that eggs are a rich source of protein whether raw or boiled. Being a relatively inexpensive and accessible food, the benefits of consuming eggs of various bird species should be maximized especially by people of the lower economic class. This will help in reducing the incidences of Protein Energy Malnutrition-PEM (which occurs as a result of insufficient protein and energy intake) and facilitate proper development of children, as eggs have been found to contain all the essential amino acids required for growth.

The present investigation further reveals appreciable increase in the quantities of individual mineral elements in the boiled forms of the various egg species (Figure 1). It has been reported that cooking methods affect the content of micronutrient composition of certain foods [18] [19]. Some studies have shown a decrease in the mineral composition of some foods when boiled [20]. This is not the case with the results from this study probably because eggs are boiled enclosed in their shells and this reduces volatile losses. In a recent study by Siulapwa et al. eggshells have been found to be rich in calcium, phosphorus, sodium, potassium, iron, zinc and magnesium [21]. It is plausible that during boiling, some minerals may be trans located from the eggshell into the albumen. This could be responsible for the increased mineral composition of the boiled egg 


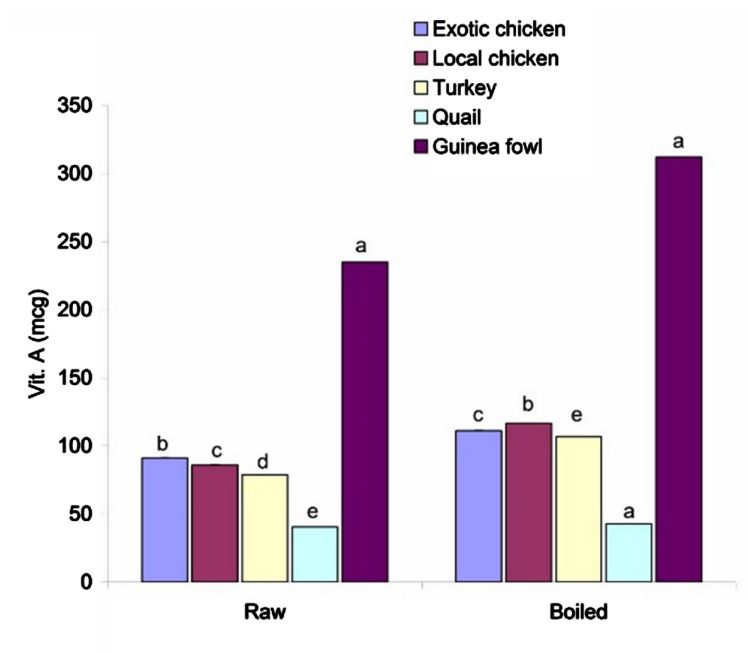

Vitamin A
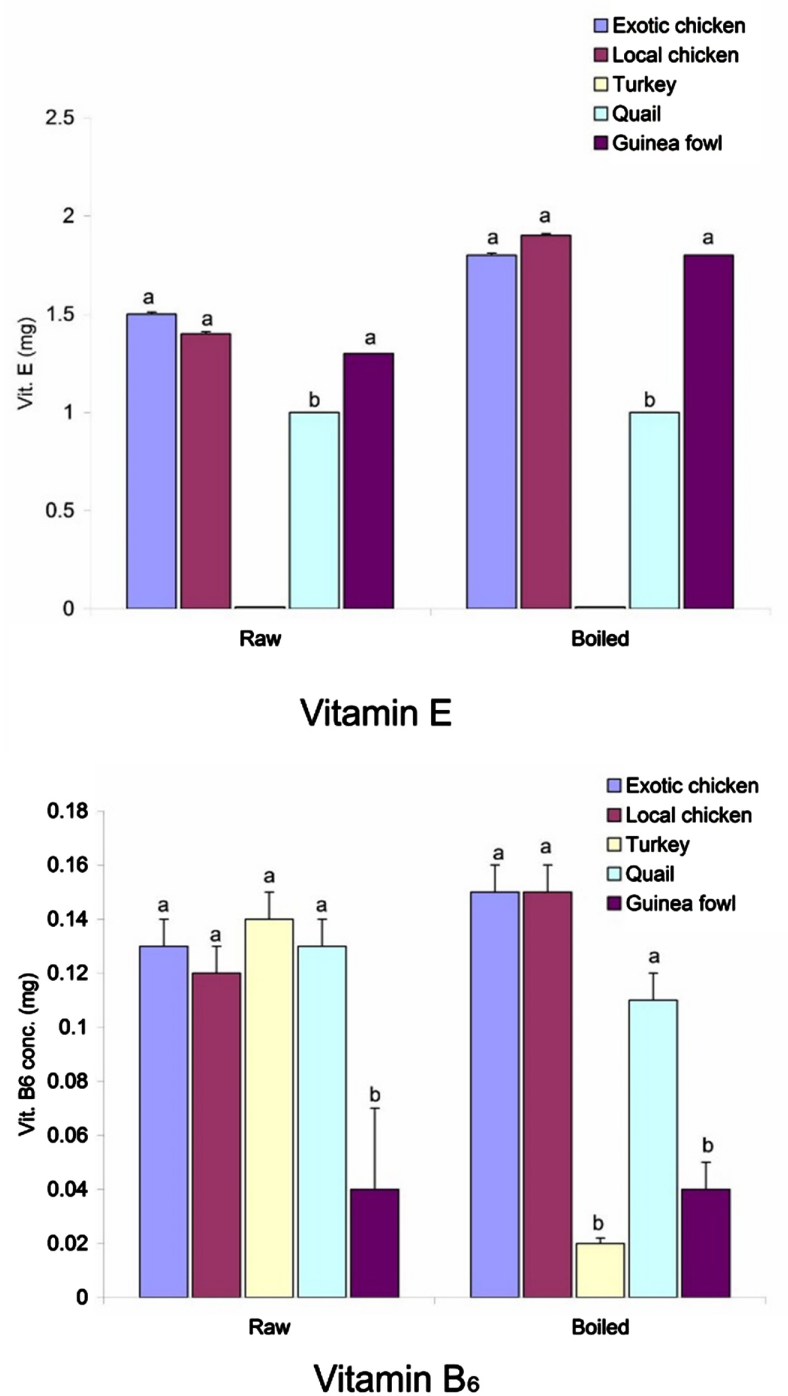
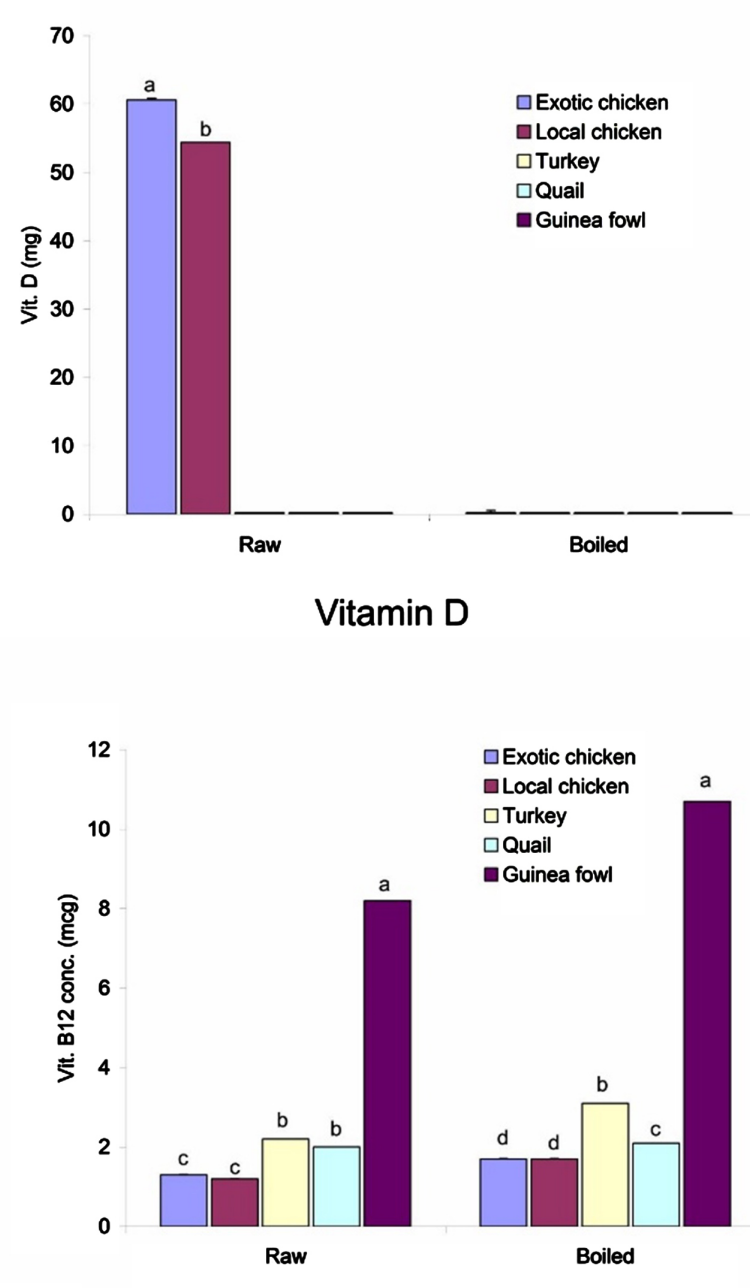

Vitamin $B_{12}$

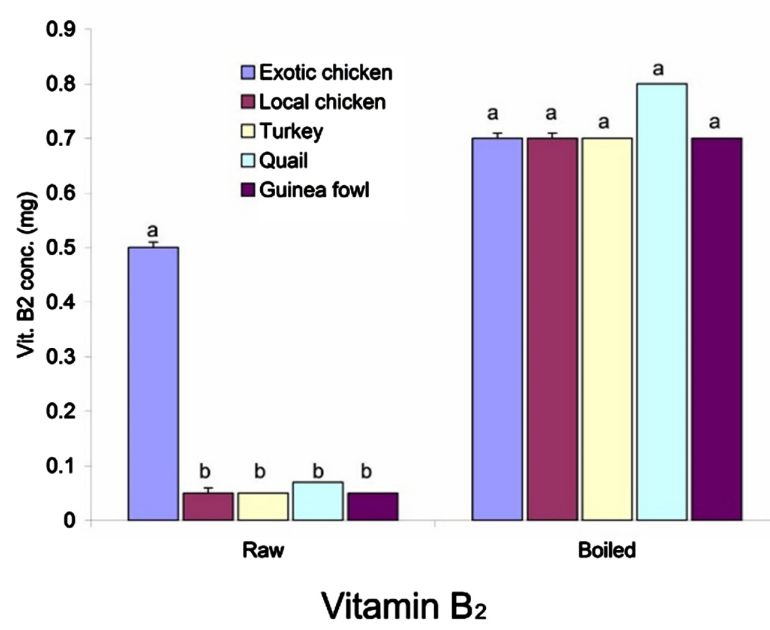

Values are presented as mean \pm SEM of 3 determinants Samples with similar symbols are homogenous

Figure 2. Comparison of vitamin composition of raw and boiled eggs per $100 \mathrm{~g}$ of edible portion. 
Table 1. Proximate and Energy composition of raw and boiled egg samples per $100 \mathrm{~g}$ edible portion.

\begin{tabular}{|c|c|c|c|c|c|c|c|c|c|}
\hline & $\begin{array}{c}\text { Moisture } \\
(\%)\end{array}$ & Protein (\%) & Fat (\%) & Ash (\%) & $\begin{array}{c}\text { Total carb } \\
(\%)\end{array}$ & Sugars (\%) & $\begin{array}{c}\text { Energy KJ } \\
(\mathrm{Kcal})^{*}\end{array}$ & $\begin{array}{l}\text { Energy } \\
(\mathrm{KJ})^{* *}\end{array}$ & $\begin{array}{l}\text { Energy } \\
(\mathrm{Kcal})^{\star *}\end{array}$ \\
\hline \multicolumn{10}{|l|}{ RAW SAMPLES } \\
\hline Exotic chicken & $69.2 \pm 0.20^{c}$ & $15.2 \pm 0.07^{\mathrm{c}}$ & $12.3 \pm 0.09^{\mathrm{b}}$ & $1.6 \pm 0.03^{c}$ & $1.7^{\mathrm{a}}$ & $1.4 \pm 0.06^{\mathrm{a}}$ & $746(178)^{\mathrm{b}}$ & $832.6^{c}$ & $199 \pm 0.49^{c}$ \\
\hline Local chicken & $74.6 \pm 0.58^{\mathrm{a}}$ & $12.7 \pm 0.25^{\mathrm{d}}$ & $10.4 \pm 0.23^{c}$ & $1.1 \pm 0.06^{\mathrm{c}}$ & $1.2^{\mathrm{b}}$ & $1.0 \pm 0.03^{\mathrm{a}}$ & $628(150)^{\mathrm{e}}$ & $769.9^{\mathrm{e}}$ & $184 \pm 0.10^{\mathrm{e}}$ \\
\hline Turkey & $68.8 \pm 0.46^{\mathrm{c}}$ & $11.5 \pm 0.44^{\mathrm{e}}$ & $13.0 \pm 0.06^{\mathrm{b}}$ & $5.4 \pm 0.03^{\mathrm{a}}$ & $1.3^{\mathrm{b}}$ & $1.1 \pm 0.03^{\mathrm{a}}$ & $711(170)^{\mathrm{d}}$ & $1097.5^{\mathrm{b}}$ & $262.3 \pm 0.23^{\mathrm{b}}$ \\
\hline Quail & $70.7 \pm 0.50^{\mathrm{b}}$ & $15.6 \pm 0.10^{\mathrm{b}}$ & $11.9 \pm 0.09^{\mathrm{b}}$ & $1.0 \pm 0.03^{c}$ & $0.8^{c}$ & $0.5 \pm 0.06^{\mathrm{b}}$ & $728(174)^{c}$ & $793.3^{\mathrm{d}}$ & $189.6 \pm 0.23^{\mathrm{d}}$ \\
\hline Guinea fowl & $61.0 \pm 0.24^{\mathrm{d}}$ & $20.3 \pm 0.15^{\mathrm{a}}$ & $13.8 \pm 0.17^{\mathrm{a}}$ & $4.2 \pm 0.06^{\mathrm{b}}$ & $0.7^{\mathrm{c}}$ & $0.5 \pm 0.03^{\mathrm{b}}$ & $871(208)^{a}$ & $1342.6^{\mathrm{a}}$ & $320.9 \pm 0.38^{\mathrm{a}}$ \\
\hline \multicolumn{10}{|c|}{ BOILED SAMPLES } \\
\hline Exotic chicken & $62.2 \pm 0.66^{\mathrm{b}}$ & $19.3 \pm 0.03^{b}$ & $15.1 \pm 0.06^{c}$ & $1.7 \pm 0.06^{c}$ & $1.7^{\mathrm{a}}$ & $1.6 \pm 0.03^{\mathrm{a}}$ & $920(220)^{b}$ & $1042.2^{\mathrm{c}}$ & $249.1 \pm 0.51^{c}$ \\
\hline Local chicken & $60.9 \pm 0.39^{c}$ & $18.6 \pm 0.38^{\mathrm{b}}$ & $15.0 \pm 0.09^{c}$ & $3.8 \pm 0.07^{\mathrm{b}}$ & $1.7^{\mathrm{a}}$ & $1.4 \pm 0.06^{\mathrm{a}}$ & $904(216)^{c}$ & $1033.4^{\mathrm{c}}$ & $247.0 \pm 0.30^{c}$ \\
\hline Turkey & $61.2 \pm 0.46^{\mathrm{c}}$ & $14.2 \pm 0.20^{\mathrm{d}}$ & $17.4 \pm 0.09^{\mathrm{b}}$ & $5.4 \pm 0.03^{\mathrm{a}}$ & $1.8^{\mathrm{a}}$ & $1.6 \pm 0.03^{\mathrm{a}}$ & $925(221)^{\mathrm{b}}$ & $1495.8^{\mathrm{b}}$ & $357.5 \pm 0.30^{\mathrm{b}}$ \\
\hline Quail & $69.3 \pm 0.50^{\mathrm{a}}$ & $16.1 \pm 0.15^{\mathrm{c}}$ & $12.5 \pm 0.03^{\mathrm{d}}$ & $1.5 \pm 0.03^{\mathrm{c}}$ & $0.2^{\mathrm{c}}$ & $0.4 \pm 0.03^{\mathrm{b}}$ & $745(178)^{\mathrm{d}}$ & $835.9^{\mathrm{d}}$ & $199.8 \pm 0.33^{\mathrm{d}}$ \\
\hline Guinea fowl & $50.3 \pm 0.20^{\mathrm{d}}$ & $26.6 \pm 0.06^{\mathrm{a}}$ & $18.0 \pm 0.15^{\mathrm{a}}$ & $4.0 \pm 0.12^{\mathrm{b}}$ & $1.1^{\mathrm{b}}$ & $0.9 \pm 0.06^{\mathrm{b}}$ & $1138(272)^{\mathrm{a}}$ & $1775.7^{\mathrm{a}}$ & $324.4 \pm 0.87^{\mathrm{a}}$ \\
\hline
\end{tabular}

Values are represented as mean \pm SEM of 3 determinants. Values with different superscript in the same column are significantly different $(p<0.05)$ from each other. ${ }^{*}$ Energy values (KJ) were calculated using Atwater values; ${ }^{*}$ Energy values were gotten using bomb calorimetry.

samples. Hence, eggs supply an array of important micro and macro elements in significant quantities. This can be employed in combating micronutrient deficiencies such as anemia and rickets, which are prevalent among underdeveloped and undernourished populations. Also, the sodium content of the eggs were high with the boiled eggs having higher values. Excessive sodium intake can be a risk factor for nervous and cardiovascular diseases. Potassium content was slightly lower than sodium but phosphorus content was much higher. Excessive sodium intake can be a risk factor for nervous and cardiovascular diseases but where the sodium-potassium ratio $(\mathrm{Na}: \mathrm{K})$ is adequate, this risk is greatly reduced; this has been reported by recent research [22]. Results of this research show the potassium content of the eggs being slightly lower than sodium making the $\mathrm{Na}: \mathrm{K}$ of the eggs a little greater than one, except for guinea fowl egg (both raw and boiled) which had its Na:K less than one. The American Heart Association (AHA) recommendations for sodium (2300 $\mathrm{mg} /$ day) and potassium (4700 $\mathrm{mg} /$ day) intake suggest a healthy ratio of about 1:2 (i.e. 0.5) [23]. Only guinea fowl egg had close to this adequate ratio hence, frequent intake of the other eggs may need to be accompanied by intake of other potassium-rich foods (such as banana, potatoes and nuts) in order to improve the $\mathrm{Na}: \mathrm{K}$ of individuals.

In general, the micronutrient composition for the egg samples is similar to that reported in the USDA database [24]. In the case of vitamin D which was found in trace amounts in all but two raw samples, cooking significantly altered its content in the boiled samples (Figure 2). This differs from the report of Mattila et al. who studied the retention of vitamin D (25-hydroxycholecalciferol) in yolks of eggs cooked for 10 mins [25]. Vitamin D losses of less than $10 \%$ were 
recorded and hence it was concluded that household cooking seemed not to significantly reduce vitamin $\mathrm{D}$ content of foods. This contrast may be attributable to differences in study design, methods (HPLC was used to estimate vitamin D in that study while spectrometry, which is a more sensitive method, was used in this study), and variations in species of bird eggs used. Vitamin D plays an important role in bone metabolism and is only naturally present in a few foods. Vitamin A content was higher in the boiled egg samples; this is supported by the results from Musa and Ogbadoyi [20], who noted an increase in the beta carotene content of certain boiled vegetables. In addition to vitamin A, eggs contain lutein and zeaxanthin (carotenoids), which aid in the prevention of macular degeneration [26]; thus, eggs play a major role in maintenance of eye health and prevention of night blindness.

Guinea fowl eggs due to their relatively higher protein and micronutrient content, should be recommended especially for children prone-to or combating PEM and various micronutrient deficiencies. The relatively lower fat content of quail eggs make them healthier for individuals watching their dietary fat intake. Most of the micronutrients in eggs constitute a good percentage of the recommended dietary allowances; hence eggs contribute significantly in providing adequate diets and maintaining good health.

\section{Conclusion}

The results from this study show that apart from the popularly consumed chicken egg, other egg species are also highly nutritious and healthy for consumption. It is recommended that these other less-popular species be incorporated into the diets of both children and adults as they provide most of the essential macro and micro nutrients in significant amounts, both in their raw and boiled forms.

\section{Conflict of Interests}

The authors declare no competing financial interest; the project was solely funded by the authors.

\section{References}

[1] WHO (2015) World Health Statistics 2015. Global Health Observatory (GHO) Data.

[2] International Policy Research Institute, 2015.

[3] UNICEF/WHO/World Bank (2015) Joint Child Malnutrition Estimates-Levels and Trends (2015 Edition). Global Database on Child Growth and Malnutrition. UNICEF-WHO-The World Bank Group.

[4] FAO (2013) Combating Micronutrient Deficiencies: Food-Based Approaches. In: Thompson, B. and Amoroso, L., Eds., Food and Agriculture Organization of the United Nations.

[5] FAO (2007) The State of the World's Animal Genetic Resources for Food and Agriculture. Barbara Rischowsky and Dafydd Pilling, FAO, Rome. 
[6] Pamplona-Roger, D. (2004) Encyclopedia of Foods and Their Healing Power (Volume 1). Education and Health Library. Review and Herald Publishing.

[7] Onyeabochukwu, D.A. (2007) Cultural Practices and Health: The Nigerian Experience. Medikka: Journal of the University of Nigeria Medical Students.

[8] Burlingame, B., Mouille, B. and Charrondiere, R. (2009) Nutrients, Bioactive NonNutrients and Anti-Nutrients in Potatoes. Journal of Food Composition \& Analysis, 22, 494-502. https://doi.org/10.1016/j.jfca.2009.09.001

[9] Tolik, D., Polawska, E., Charuta, A., Nowaczewski, S. and Cooper, R. (2014) Characteristics of Egg Parts, Chemical Composition and Nutritive Value of Japanese Quail Eggs-A Review. Folia Biologica (Krakow), 62, 287-292. https://doi.org/10.3409/fb62_4.287

[10] AOAC (2005) Official Methods of Analysis. 16th Edition, Association of Official Analytical Chemists, Arlington, 806-842.

[11] Will, R. and Greenfield, H. (1984) Laboratory Instruction Manual for Food Composition Studies. The University of New South Wales, 59.

[12] Atwater, W.O. and Bryant, A.P. (1900) The Availability and Fuel Value of Food Materials. US Government Printing Office, Experimental Station 12th Annual Report, Washington DC, 73-110.

[13] AOAC (1990) Official Methods of Analysis. 15th Edition, Association of Official Analytical Chemists, Washington DC.

[14] Byrdwell, W.C. (2009) Comparison of Analysis of Vitamin $\mathrm{D}_{3}$ in Foods Using U1traviolet and Mass Spectrometric Detection. Journal of Agricultural and Food Chemistry, 57, 2135-2146. https://doi.org/10.1021/jf803398u

[15] Ogunwole, O.A., Ojelade, A.Y., Oyewo, M.O. and Essien, E.A. (2015) Proximate Composition and Physical Characteristics of Eggs from Laying Chickens Fed Different Proprietary Vitamin-Mineral Premixes under Two Rearing Systems during Storage. International Journal of Food Science and Nutrition Engineering, 5, 59-67.

[16] Song, K.T., Choi, S.H. and Oh, H.R. (2000) A Comparison of Egg Quality of Pheasant, Chukar, Quail and Guinea Fowl. Asian-Australian Journal of Animal Science, 13, 986-990. https://doi.org/10.5713/ajas.2000.986

[17] Fakai, I.M., Sani, I. and Olalekan, O.S. (2015) Proximate Composition and Cholesterol Content of Eggs Obtained from Various Bird Species. Journal of Harmonized Research in Medical and Health Sciences, 2, 18-25.

[18] Cieslik, E., Leszczynska, T., Filipiak-Florkiewicz, A., Sikora, E. and Pisulewski, P.M. (2007) Effects of Some Technological Processes on Glucosinolate Contents in Cruciferous Vegetables. Food Chemistry, 105, 976-981. https://doi.org/10.1016/j.foodchem.2007.04.047

[19] Evenepoel, P., Geypens, B., Luypaerts, A., Hiele, M., Ghoos, Y. and Rutgeerts, P. (1998) Digestibility of Cooked and Raw Egg Protein in Humans as Assessed by Stable Isotope Techniques-Randomized Control Trial. Journal of Nutrition, 128, 1716-1722. https://doi.org/10.1093/jn/128.10.1716

[20] Musa, A. and Ogbadoyi, E.O. (2012) Effect of Processing Methods on Some Micronutrients, Antinutrients and Toxic Substances in Hibiscus Sabdariffa. Asian Journal of Biochemistry, 7, 63-79. https://doi.org/10.3923/ajb.2012.63.79

[21] Siulapwa, N., Mwambungu, A. and Mubbunu, L. (2014) Comparison of Mineral Composition of Commercial Hen Egg Shells to Fresh Water Crocodile Egg Shells. International Journal of Research in Agriculture and Food Science, 2, 16-18.

[22] Yang, Q., Liu, T. and Kuklina, E.V. (2011) Sodium and Potassium Intake and Mor- 
tality among US Adults: Prospective Data from the Third National Health and Nutrition Examination Survey. Archives of Internal Medicine, 171, 1183-1191. https://doi.org/10.1001/archinternmed.2011.257

[23] American Health Association (AHA) (2008) Diet and Lifestyle Recommendations. http://www.americanheart.org/presenter.jhtml

[24] USDA (2016) National Nutrient Database for Standard Reference Release 28.

[25] Mattila, P., Ronkainen, R. and Piironen, V. (1999) Effect of Household Cooking on the Vitamin D content in Fish, Eggs and Wild Mushrooms. Journal of Food Composition and Analysis, 12, 153-160. https://doi.org/10.1006/jfca.1999.0828

[26] Abdel-Aal, E.M., Akhtar, H., Zaheer, K. and Ali, R. (2013) Dietary Sources of Lutein and Zeaxanthin Carotenoids and Their Role in Eye Health. Nutrients, 5, 1169-1185. https://doi.org/10.3390/nu5041169 